\title{
Impact of selected agrotechnical factors on the occurrence of pests in maize cultivation (Zea mays L.)
}

\author{
Wpływ wybranych czynników agrotechnicznych \\ na występowanie szkodników w uprawie kukurydzy (Zea mays L.)
}

\author{
Piotr Szulc ${ }^{1 *}$, Katarzyna Ambroży-Deręgowska², Iwona Mejza², Daniel Krauklis ${ }^{3}$
}

\section{Summary}

The objective of presented in this paper the results of the 4-year field research was an evaluation of effect of two-component (NP) fertilizer placement depth, the type of nitrogen fertilizer and the date of its application on the occurrence of pests in maize cultivation. Changing weather conditions in the years of performing the field studies significantly differentiated the percentage of maize plants damaged by pests. The depth of NP fertilizer application did not have a significant impact on the number of plants damaged by the European maize borer [Ostrinia nubilalis (Hübner)], frit fly (Oscinella frit L.) and cereal leaf beetle (Oulema melanopus). Frit fly damaged plants fertilized with ammonium nitrate at higher degree than the plants fertilized with urea. In-season sidedress nitrogen application at the $\mathrm{BBCH} 15 / 16$ growth stage increased the percentage of plants damaged by cereal leaf beetle compared to the pre-sowing $\mathrm{N}$ application. Regardless of the years of research and the NP fertilizer placement depth, significantly the smallest damage to plants caused by cereal leaf beetle was recorded for pre-sowing application of ammonium nitrate or urea and significantly the greatest when ammonium nitrate was applied in season at the BBCH 15/16 growth phase.

Key words: maize, fertilization placement depth, nitrogen, pests

\section{Streszczenie}

W pracy przedstawiono wyniki 4-letnich badań polowych, których celem była ocena wpływu głębokości umieszczania nawozu mineralnego, dwuskładnikowego (NP) w warstwie gleby, rodzaju nawozu azotowego oraz terminu jego aplikacji na występowanie szkodników w uprawie kukurydzy. Zmienne warunki pogodowe w latach badań, w istotny sposób różnicowały odsetek roślin kukurydzy uszkodzonych przez szkodniki. Głębokość aplikacji nawozu NP nie miała istotnego wpływu na ilość roślin uszkodzonych przez omacnicę prosowiankę [Ostrinia nubilalis (Hübner)], ploniarkę zbożówkę (Oscinella frit L.) i skrzypionkę zbożową (Oulema melanopus). Ploniarka zbożówka w większym stopniu uszkadzała rośliny nawożone saletrą amonową, w porównaniu do mocznika. Pogłówna aplikacja azotu w fazie BBCH 15/16 zwiększała odsetek roślin uszkodzonych przez skrzypionkę zbożową, w stosunku do przedsiewnej aplikacji tego składnika. Niezależnie od lat badań i głębokości aplikacji nawozu NP, istotnie najmniejsze uszkodzenia roślin przez skrzypionkę zbożową odnotowano po zastosowaniu saletry amonowej lub mocznika przed siewem kukurydzy, a istotnie największe, gdy zastosowano saletrę amonową w fazie BBCH 15/16.

Słowa kluczowe: kukurydza, głębokość nawożenia, azot, szkodniki

\author{
${ }^{1}$ Uniwersytet Przyrodniczy w Poznaniu, Katedra Agronomii \\ Dojazd 11, 60-632 Poznań \\ ${ }^{2}$ Uniwersytet Przyrodniczy w Poznaniu, Katedra Metod Matematycznych i Statystycznych \\ Wojska Polskiego 28, 60-637 Poznań \\ ${ }^{3}$ Stacja Doświadczalna Oceny Odmian w Chrząstowie \\ Chrząstowo 8, 89-100 Nakło nad Notecią \\ *corresponding author: piotr.szulc@up.poznan.pl \\ ORCID: 0000-0002-9670-3231
}




\section{Wstęp / Introduction}

Jednym z podstawowych elementów agrotechniki roślin zbożowych decydującym o wielkości uzyskiwanego plonu ziarna o odpowiedniej jakości jest nawożenie (Ladha i wsp. 2005; Ciampitti i Vyn 2013). Kompleksowe, a zarazem pełne zaopatrzenie roślin w łatwo dostępne składniki pokarmowe decyduje o prawidłowym rozwoju systemu korzeniowego i przebiegu procesów fizjologicznych w roślinie, co przekłada się bezpośrednio na tworzenie plonu oraz odpowiednią jego jakość. Efektywność stosowanego nawożenia zależy między innymi od warunków glebowo-klimatycznych w okresie wegetacji oraz zastosowanych nawozów, które należy aplikować tak, aby pobieranie składników w nich zawartych przez rośliny przebiegało zgodnie z ich rytmem rozwojowym (Scharf i wsp. 2002; Ziadi i wsp. 2007). Aktualnie zwiększanie produkcji roślinnej, ukierunkowane jest na bardziej efektywne wykorzystanie składników z dawki nawozu mineralnego (Setiyono i wsp. 2010; Ciampitti i Vyn 2013). Stąd też stałym kierunkiem badań nad rolą azotu i fosforu w kształtowaniu produkcji roślinnej (plonu) jest wyznaczenie biologicznie i ekonomicznie uzasadnionych optymalnych jego dawek z uwzględnieniem czynników kształtujących pobranie i wykorzystanie tych pierwiastków z nawozów mineralnych (Setiyono i wsp. 2010; Belanger i wsp. 2011). Stosowane w praktyce rolniczej, przedsiewne i pogłówne nawożenie, prowadzi często do przedawkowania składnika pokarmowego i stwarza zagrożenie dla środowiska naturalnego (Szulc i Bocianowski 2014; Szulc i wsp. 2015, 2018). Nawożenie mineralne roślin uprawnych nie tylko kształtuje wielkość plonu, ale jest również bardzo ważnym czynnikiem modyfikującym ich zdrowotność (Bocianowski i wsp. 2016). Stosowanie zabiegów chemicznych $\mathrm{w}$ ochronie roślin przeciwko szkodnikom może być bardzo utrudnione i może wpływać na jakość uzyskanego ziarna. Do tego celu od 1 stycznia 2014 roku wykorzystywana jest tzw. integrowana ochrona roślin, wprowadzona do unijnego prawodawstwa mocą dyrektywy Parlamentu Europejskiego i Rady nr 2009/128/WE (Dyrektywa 2009). W integrowanej ochronie kukurydzy przed chorobami i szkodnikami bardzo ważne jest prawidłowe nawożenie (żywienie) roślin. Decyduje ono nie tylko o wielkości plonu, ale zwiększa ponadto tolerancję roślin na porażenie przez choroby i żerowanie szkodników. Potwierdza to Krauss (2001), według którego stopień presji agrofaga na roślinę uprawną jest wypadkową stanu jej odżywienia. Dlatego tak ważnym elementem prac agronomicznych jest poszukiwanie alternatywnych metod ograniczania wpływu szkodników na rośliny uprawne. Hipoteza doświadczenia zakładała, że czynniki agrotechniczne (technika aplikacji nawozu, nawóz azotowy, termin aplikacji nawozu) mogą w istotny sposób kształtować występowanie szkodników na roślinach kukurydzy. Wrażliwość roślin na atak patogenów zdaniem Grzebisza i wsp. (2007) wynika nie tylko z jej cech genetycznych, lecz także z warunków wzrostu dla obu grup organizmów (roślina - patogen).

Celem przeprowadzonych badań polowych była ocena występowania szkodników w uprawie kukurydzy w warunkach zastosowania zróżnicowanych czynników agrotechnicznych.

\section{Materiały i metody / Materials and methods}

\section{Układ doświadczenia / Experimental design}

Doświadczenie polowe wykonano w Katedrze Agronomii Uniwersytetu Przyrodniczego w Poznaniu, na polach Zakładu Dydaktyczno-Doświadczalnego Gorzyń w latach 2015-2018. Prowadzono je przez 4 lata w tym samym schemacie, $w$ układzie split-split-plot $\mathrm{z}$ trzema czynnikami, w 4 powtórzeniach polowych. Badano następujące zmienne: A - czynnik 1. rzędu - głębokość wysiewu nawozu NP [A1 $-0 \mathrm{~cm}$ (nawożenie rzutowe), $\mathrm{A} 2-5 \mathrm{~cm}$ (rzędowe), A3 - $10 \mathrm{~cm}$ (rzędowe), A4 - $15 \mathrm{~cm}$ (rzędowe)]; B - czynnik 2. rzędu - rodzaj uzupełniającego nawozu azotowego [B1 - saletra amonowa, B2 - mocznik]; C - czynnik 3. rzędu - termin wysiewu uzupełniającej dawki azotu [C1 - przed siewem, C2 - pogłównie w fazie BBCH 15/16]. Na wszystkich obiektach doświadczalnych stosowano jednakowy poziom nawożenia w wysokości $100 \mathrm{~kg} \mathrm{~N} / \mathrm{ha}, 70 \mathrm{~kg} \mathrm{P}_{2} \mathrm{O}_{5} / \mathrm{ha}$ i $130 \mathrm{~kg} \mathrm{~K}$ O/ha. Nawożenie bilansowano względem fosforu, który w całości w wymaganej dawce zastosowano $\mathrm{w}$ formie fosforanu amonu $\left(18 \% \mathrm{~N}, 46 \% \mathrm{P}_{2} \mathrm{O}_{5}\right)$, zgodnie ze schematem doświadczenia w ramach czynnika 1. rzędu. Nawożenie N i K wykonano przed siewem kukurydzy i zastosowano w formie mocznika $(46 \% \mathrm{~N})$ oraz soli potasowej $\left(60 \% \mathrm{~K}_{2} \mathrm{O}\right)$. Głębokość aplikacji nawozu NP została wykonana zgodnie z poziomami czynnika 1. rzędu. Siew kukurydzy wykonano siewnikiem punktowym, z nabudowanym aplikatorem nawozów granulowanych firmy Monosem. Glebę pola doświadczalnego zaliczono do IV kompleksu przydatności rolniczej (żytni bardzo dobry) oraz klasy bonitacyjnej IIIb. Siew kukurydzy wykonano w następujących terminach: 2015 (24.IV), 2016 (28.IV), 2017 (25.IV), 2018 (24.IV), natomiast omłotu kukurydzy na ziarno dokonano: 2015 (6.X), 2016 (28.IX), 2017 (17.X), 2018 (3.IX).

\section{Warunki meteorologiczne / Metorological conditions}

Warunki termiczne podczas wegetacji kukurydzy w latach prowadzenia badań były zbliżone do siebie i wynosiły średnio $15,2^{\circ} \mathrm{C}$ w roku $2015 ; 15,6^{\circ} \mathrm{C}$ w roku $2016 ; 14,2^{\circ} \mathrm{C}$ w roku 2017 oraz $16,6^{\circ} \mathrm{C}$ w roku 2018 (tab. 1). Zdecydowanie większe różnice pomiędzy latami badań wystąpiły w sumie opadów atmosferycznych. Największą ich sumę odnotowano w roku $2017(553,0 \mathrm{~mm})$, natomiast najmniejszą sumę opadów atmosferycznych odnotowano w pierwszym i ostatnim roku badań: odpowiednio $279,3 \mathrm{~mm}$ oraz $230,3 \mathrm{~mm}$ (tab. 1). Wyliczone współczynniki hydrotermiczne zabez- 
Tabela 1. Warunki pogodowe w latach badań

Table 1. Weather conditions during the years of the study

\begin{tabular}{|c|c|c|c|c|c|c|c|c|}
\hline \multirow{2}{*}{$\begin{array}{l}\text { Rok } \\
\text { Year }\end{array}$} & \multicolumn{8}{|c|}{ Temperatura - Temperature $\left[{ }^{\circ} \mathrm{C}\right]$} \\
\hline & IV & $\mathrm{V}$ & VI & VII & VIII & IX & $X$ & $\begin{array}{c}\text { średnia/suma } \\
\text { mean/sum }\end{array}$ \\
\hline 2015 & 9,3 & 13,9 & 16,9 & 20,1 & 23,4 & 15,2 & 8,2 & 15,2 \\
\hline 2016 & 9,6 & 16,3 & 19,9 & 20,3 & 19 & 17,3 & 8,4 & 15,8 \\
\hline 2017 & 7,3 & 13,7 & 17,4 & 18,0 & 18,9 & 13,3 & 10,6 & 14,2 \\
\hline 2018 & 12,9 & 16,9 & 18,5 & 20,2 & 21,3 & 15,8 & 10,9 & 16,6 \\
\hline \multicolumn{9}{|c|}{ Opady - Precipitation $[\mathrm{mm}]$} \\
\hline 2015 & 17,6 & 27,2 & 66,6 & 85,4 & 35,4 & 28,1 & 19 & 279,3 \\
\hline 2016 & 47,3 & 47,3 & 123,8 & 132,8 & 50,3 & 4,6 & 105 & 511,1 \\
\hline 2017 & 40,6 & 56,8 & 68,2 & 168,0 & 82,0 & 45,6 & 91,8 & 553,0 \\
\hline 2018 & 36,2 & 17,4 & 25,6 & 70,5 & 11,6 & 44,2 & 24,8 & 230,3 \\
\hline \multicolumn{9}{|c|}{ Wartość wskaźnika Sielianinowa w okresie wegetacji kukurydzy - Values of the Selyaninov HTC coefficient during maize vegetation } \\
\hline 2015 & 0,63 & 0,63 & 1,31 & 1,37 & 0,48 & 0,61 & 0,74 & 0,82 \\
\hline 2016 & 1,64 & 0,93 & 2,07 & 2,11 & 0,85 & 0,08 & 4,03 & 1,67 \\
\hline 2017 & 1,85 & 1,33 & 1,30 & 3,01 & 1,39 & 1,14 & 2,79 & 1,82 \\
\hline 2018 & 0,93 & 0,33 & 0,46 & 1,12 & 0,17 & 0,93 & 0,73 & 0,67 \\
\hline
\end{tabular}

pieczenia w wodę według Sielianinowa (Molga 1986) (tab. 1) uwzględniające w sposób kompleksowy zarówno temperatury powietrza, jak i opady atmosferyczne pozwoliły stwierdzić, że warunki pogodowe dla wzrostu i rozwoju kukurydzy w dwóch latach badań były korzystne (20162017), natomiast w latach 2015 i 2018 były niekorzystne ze względu na okresowe niedobory wilgoci w glebie.

\section{Analiza statystyczna / Data analysis}

Ze względu na uzyskane dane, mające rozkład dwumianowy wyrażony $\mathrm{w}$ procentach $(0-20 \%)$ zastosowano transformację Blissa (Arc $\sin \sqrt{x}$ ) (tab. 3-5). Na przekształconych danych wykonano czterokierunkową analizę wariancji (ANOVA) zgodnie z układem doświadczenia. Dla efektów głównych i interakcyjnych, istotnych przy poziomie istotności $\alpha=0,01$ lub $\alpha=0,05$, zastosowano odpowiednio procedurę HSD Tukeya (STATISTICA v. 13). W pracy notowano wyłącznie liczbę roślin, które zostały zaatakowane przez danego szkodnika, a wynik wyrażono w procentach uszkodzenia roślin. W fazie BBCH 17/18 oceniano występowanie ploniarki zbożówki i skrzypionki zbożowej, natomiast występowanie omacnicy prosowianki w fazie BBCH $87-89$.

\section{Wyniki i dyskusja / Results and discussion}

W wyniku przeprowadzonych czteroletnich badań polowych stwierdzono, że niezależnie od głębokości aplikacji nawozu NP, rodzaju nawozu azotowego oraz terminu aplikacji uzupełniającej dawki azotu, istotnie największe uszkodzenia roślin przez szkodniki wystąpiły: w roku 2016 dla Ostrinia nubilalis Hbn., w latach 2016-2017 dla Oscinella frit L. oraz w latach 2016-2018 dla Oulema melanopus (tab. 2, 3). $\mathrm{W}$ badaniach własnych nie stwierdzono istotnego wpływu badanych czynników doświadczenia oraz ich interakcji na procent roślin uszkodzonych przez $O$. nubilalis. Ploniarka zbożówka natomiast, silniej uszkodziła rośliny kukurydzy w roku 2016 (7,31\%) i 2017 (8,30\%), natomiast najmniejszą presję tego szkodnika odnotowano w roku 2015 (3,50\%) i 2018 (1,75\%) (tab. 3). Według Beresia (2011), występowanie $O$. frit zależy ściśle od warunków pogodowych panujących wczesną wiosną. Wilgotna i chłodna wiosna w początkowych fazach rozwojowych kukurydzy zwiększa uszkodzenie roślin przez tego szkodnika (Szulc i Bocianowski 2014), co wykazano w badaniach własnych. Niezależnie od lat badań, wpływ głębokości aplikacji nawozu NP nie różnicował uszkodzeń przez tego szkodnika. Stwierdzono, że niezależnie od lat badań $O$. frit silniej uszkodziła rośliny, gdy zastosowano jako nawóz azotowy saletrę amonową (5,67\%), w stosunku do mocznika (4,76\%). Z kolei większą presję skrzypionki zbożowej odnotowano, gdy zastosowano azot w fazie 5-6 liści rośliny (BBCH 15/16), w stosunku do aplikacji tego składnika przed siewem kukurydzy (tab. 3). W badaniach własnych, niezależnie od lat badań, termin zastosowania uzupełniającej dawki azotu nie różnicował procentu roślin uszkodzonych przez $O$. nubilalis (tab. 4). Z kolei we wcześniejszej pracy autora (Szulc 2013) stosowanie PK przed siewem i N w fazie BBCH 15/16 w istotny sposób zwiększało ilość uszkodzeń roślin kukurydzy powodowanych przez $O$. nubilalis, w porównaniu do przedsiewnej aplikacji NPK. Szkodliwość tego gatunku wiąże się ze wzrostem 
Tabela 2. Uszkodzenia roślin przez szkodniki i wyniki analizy wariancji Table 2. Damage of plants caused by pests and ANOVA results

\begin{tabular}{|c|c|c|c|c|}
\hline \multirow{2}{*}{$\begin{array}{l}\text { Źródła zmienności } \\
\text { Sources of variations }\end{array}$} & \multirow{2}{*}{$\begin{array}{c}\text { Stopnie swobody } \\
\text { Degrees } \\
\text { of freedom }\end{array}$} & \multicolumn{3}{|c|}{$\begin{array}{l}\text { Średnie kwadraty } \\
\text { Mean squares }\end{array}$} \\
\hline & & $\begin{array}{l}\text { omacnica prosowianka } \\
\text { European corn borer }\end{array}$ & $\begin{array}{c}\text { ploniarka zbożówka } \\
\text { frit fly }\end{array}$ & $\begin{array}{l}\text { skrzypionka zbożowa } \\
\text { cereal leaf beetle }\end{array}$ \\
\hline Bloki-Blocks & 3 & 0,0016 & 0,0141 & 0,0001 \\
\hline Y - Lata - Years & 3 & $0,2936^{* *}$ & $0,3879 * *$ & $0,0584^{* *}$ \\
\hline Błąd 1 - Error 1 & 9 & 0,0287 & 0,0140 & 0,0066 \\
\hline A & 3 & 0,0110 & 0,0153 & 0,0052 \\
\hline $\mathrm{Y} \times \mathrm{A}$ & 9 & 0,0138 & 0,0085 & 0,0070 \\
\hline Błąd 2 - Error 2 & 36 & 0,0069 & 0,0065 & 0,0063 \\
\hline B & 1 & 0,0060 & $0,0358 * *$ & 0,0094 \\
\hline $\mathrm{Y} \times \mathrm{B}$ & 3 & 0,0167 & 0,0020 & 0,0022 \\
\hline $\mathrm{A} \times \mathrm{B}$ & 3 & 0,0009 & 0,0029 & 0,0025 \\
\hline $\mathrm{Y} \times \mathrm{A} \times \mathrm{B}$ & 9 & 0,0053 & 0,0034 & 0,0025 \\
\hline Błąd 3 - Error 3 & 48 & 0,0076 & 0,0036 & 0,0028 \\
\hline $\mathrm{C}$ & 1 & 0,0045 & 0,0105 & $0,1711^{* *}$ \\
\hline $\mathrm{Y} \times \mathrm{C}$ & 3 & 0,0088 & $0,0084^{*}$ & $0,0321 * *$ \\
\hline $\mathrm{A} \times \mathrm{C}$ & 3 & 0,0013 & 0,0041 & 0,0037 \\
\hline $\mathrm{B} \times \mathrm{C}$ & 1 & 0,0028 & 0,0069 & $0,0293 * *$ \\
\hline $\mathrm{Y} \times \mathrm{A} \times \mathrm{C}$ & 9 & 0,0046 & 0,0038 & 0,0008 \\
\hline $\mathrm{Y} \times \mathrm{B} \times \mathrm{C}$ & 3 & 0,0040 & $0,0181 * *$ & 0,0015 \\
\hline $\mathrm{A} \times \mathrm{B} \times \mathrm{C}$ & 3 & 0,0060 & 0,0002 & 0,0034 \\
\hline $\mathrm{Y} \times \mathrm{A} \times \mathrm{B} \times \mathrm{C}$ & 9 & 0,0053 & 0,0026 & 0,0033 \\
\hline Błąd 4 - Error 4 & 96 & 0,0040 & 0,0027 & 0,0027 \\
\hline
\end{tabular}

*różnice istotne dla $\mathrm{p}<0,05$ - significant differences at $\mathrm{p}$-value $<0.05$

$* *$ różnice istotne dla $\mathrm{p}<0,01-$ significant differences at $\mathrm{p}$-value $<0.01$

Tabela 3. Średnie wartości uszkodzenia roślin przez szkodniki dla lat i pozostałych czynników Table 3. Mean values of damage of plants caused by insects for the years and other factors

\begin{tabular}{|c|c|c|c|c|c|c|c|}
\hline \multirow{2}{*}{$\begin{array}{l}\text { Czynniki } \\
\text { Factors }\end{array}$} & \multirow{2}{*}{$\begin{array}{c}\text { Poziomy } \\
\text { czynników } \\
\text { The levels } \\
\text { of the factors }\end{array}$} & \multicolumn{2}{|c|}{$\begin{array}{l}\text { Omacnica prosowianka } \\
\text { European corn borer }\end{array}$} & \multicolumn{2}{|c|}{$\begin{array}{l}\text { Ploniarka zbożówka } \\
\text { Frit fly }\end{array}$} & \multicolumn{2}{|c|}{$\begin{array}{l}\text { Skrzypionka zbożowa } \\
\text { Cereal leaf beetle }\end{array}$} \\
\hline & & {$[\%]$} & ${ }^{\circ}$ Bliss & {$[\%]$} & ${ }^{\circ}$ Bliss & {$[\%]$} & ${ }^{\circ}$ Bliss \\
\hline \multirow{4}{*}{$\mathrm{Y}$} & 2015 & 6,24 & $0,23 \mathrm{~b}$ & 3,50 & $0,18 \mathrm{bc}$ & 1,53 & $0,10 \mathrm{~b}$ \\
\hline & 2016 & 14,27 & $0,38 \mathrm{a}$ & 7,31 & $0,26 \mathrm{ab}$ & 2,55 & $0,15 a b$ \\
\hline & 2017 & 6,04 & $0,24 \mathrm{~b}$ & 8,30 & $0,29 \mathrm{a}$ & 3,40 & $0,17 \mathrm{a}$ \\
\hline & 2018 & 6,00 & $0,24 \mathrm{~b}$ & 1,75 & $0,12 \mathrm{c}$ & 2,91 & $0,15 \mathrm{ab}$ \\
\hline \multirow{4}{*}{ A } & A1 & 9,01 & $0,29 \mathrm{a}$ & 4,08 & $0,19 \mathrm{a}$ & 2,31 & $0,13 \mathrm{a}$ \\
\hline & $\mathrm{A} 2$ & 7,98 & $0,27 \mathrm{a}$ & 5,59 & $0,22 \mathrm{a}$ & 2,68 & $0,15 \mathrm{a}$ \\
\hline & A3 & 7,33 & $0,26 \mathrm{a}$ & 6,04 & $0,23 \mathrm{a}$ & 2,71 & $0,15 \mathrm{a}$ \\
\hline & A4 & 8,23 & $0,28 \mathrm{a}$ & 5,15 & $0,21 \mathrm{a}$ & 2,69 & $0,15 \mathrm{a}$ \\
\hline \multirow{2}{*}{ B } & B1 & 8,46 & $0,28 \mathrm{a}$ & 5,67 & $0,22 \mathrm{a}$ & 2,82 & $0,15 \mathrm{a}$ \\
\hline & B2 & 7,82 & $0,27 \mathrm{a}$ & 4,76 & $0,20 \mathrm{~b}$ & 2,38 & $0,14 \mathrm{a}$ \\
\hline \multirow{2}{*}{$\mathrm{C}$} & $\mathrm{C} 1$ & 7,97 & $0,27 \mathrm{a}$ & 5,00 & $0,20 \mathrm{a}$ & 1,97 & $0,12 \mathrm{~b}$ \\
\hline & $\mathrm{C} 2$ & 8,30 & $0,28 \mathrm{a}$ & 5,43 & $0,22 \mathrm{a}$ & 3,23 & $0,17 \mathrm{a}$ \\
\hline
\end{tabular}

Wartości w kolumnach oznaczone co najmniej jedną taką samą literą nie różnią się istotnie $(\alpha=0,01)$

Values in columns marked with at least the same letter do not differ significantly $(\alpha=0.01)$ 
Tabela 4. Średnie wartości uszkodzenia roślin przez szkodniki dla kombinacji $\mathrm{Y} \times \mathrm{C}$ i B $\times \mathrm{C}$

Table 4. Mean values of damage of plants caused by insects for the combinations $\mathrm{Y} \times \mathrm{C}$ and $\mathrm{B} \times \mathrm{C}$

\begin{tabular}{|c|c|c|c|c|c|c|c|}
\hline \multirow{2}{*}{$\begin{array}{l}\text { Lata } \\
\text { Years }\end{array}$} & \multirow{2}{*}{$\begin{array}{c}\text { Termin } \\
\text { aplikacji azotu } \\
\text { The date } \\
\text { of nitrogen } \\
\text { application }\end{array}$} & \multicolumn{2}{|c|}{$\begin{array}{l}\text { Omacnica prosowianka } \\
\text { European corn borer }\end{array}$} & \multicolumn{2}{|c|}{$\begin{array}{l}\text { Ploniarka zbożówka } \\
\text { Frit fly }\end{array}$} & \multicolumn{2}{|c|}{$\begin{array}{l}\text { Skrzypionka zbożowa } \\
\text { Cereal leaf beetle }\end{array}$} \\
\hline & & {$[\%]$} & ${ }^{\circ} \mathrm{Bliss}$ & {$[\%]$} & ${ }^{\circ} \mathrm{Bliss}$ & {$[\%]$} & ${ }^{\circ}$ Bliss \\
\hline \multirow{2}{*}{2015} & $\mathrm{C} 1$ & 5,48 & $0,22 \mathrm{a}$ & 2,61 & $0,16 \mathrm{c}$ & 0,72 & $0,06 \mathrm{~d}$ \\
\hline & $\mathrm{C} 2$ & 6,99 & $0,25 \mathrm{a}$ & 4,38 & $0,20 \mathrm{~b}$ & 2,33 & $0,15 \mathrm{abc}$ \\
\hline \multirow{2}{*}{2016} & $\mathrm{C} 1$ & 14,80 & $0,38 \mathrm{a}$ & 7,31 & $0,26 \mathrm{a}$ & 1,69 & $0,13 \mathrm{bc}$ \\
\hline & $\mathrm{C} 2$ & 13,75 & $0,37 \mathrm{a}$ & 7,31 & $0,26 \mathrm{a}$ & 3,40 & $0,18 \mathrm{a}$ \\
\hline \multirow{2}{*}{2017} & $\mathrm{C} 1$ & 5,48 & $0,23 \mathrm{a}$ & 8,49 & $0,29 \mathrm{a}$ & 3,72 & $0,18 \mathrm{a}$ \\
\hline & $\mathrm{C} 2$ & 6,60 & $0,26 \mathrm{a}$ & 8,12 & $0,28 \mathrm{a}$ & 3,09 & $0,17 \mathrm{ab}$ \\
\hline \multirow{2}{*}{2018} & $\mathrm{C} 1$ & 6,12 & $0,25 \mathrm{a}$ & 1,58 & $0,11 \mathrm{~d}$ & 1,74 & $0,11 \mathrm{c}$ \\
\hline & $\mathrm{C} 2$ & 5,88 & $0,24 \mathrm{a}$ & 1,92 & $0,12 \mathrm{~cd}$ & 4,08 & $0,19 \mathrm{a}$ \\
\hline \multirow{2}{*}{$\begin{array}{c}\text { Rodzaj azotu } \\
\text { nawozowego } \\
\text { Type } \\
\text { of nitrogen } \\
\text { fertilizer }\end{array}$} & \multirow{2}{*}{$\begin{array}{l}\text { termin } \\
\text { aplikacji azotu } \\
\text { the date } \\
\text { of nitrogen } \\
\text { application }\end{array}$} & \multicolumn{2}{|c|}{$\begin{array}{l}\text { omacnica prosowianka } \\
\text { European corn borer }\end{array}$} & \multicolumn{2}{|c|}{$\begin{array}{l}\text { ploniarka zbożówka } \\
\text { frit fly }\end{array}$} & \multicolumn{2}{|c|}{$\begin{array}{l}\text { skrzypionka zbożowa } \\
\text { cereal leaf beetle }\end{array}$} \\
\hline & & {$[\%]$} & ${ }^{\circ} \mathrm{Bliss}$ & {$[\%]$} & ${ }^{\circ}$ Bliss & {$[\%]$} & ${ }^{\circ} \mathrm{Bliss}$ \\
\hline \multirow{2}{*}{$\mathrm{B} 1$} & $\mathrm{C} 1$ & 8,50 & $0,28 \mathrm{a}$ & 5,36 & $0,21 \mathrm{a}$ & 1,83 & $0,11 \mathrm{c}$ \\
\hline & $\mathrm{C} 2$ & 8,42 & $0,28 \mathrm{a}$ & 5,97 & $0,23 \mathrm{a}$ & 3,81 & $0,19 \mathrm{a}$ \\
\hline \multirow{2}{*}{$\mathrm{B} 2$} & $\mathrm{C} 1$ & 7,44 & $0,26 \mathrm{a}$ & 4,64 & $0,20 \mathrm{a}$ & 2,10 & $0,12 \mathrm{c}$ \\
\hline & $\mathrm{C} 2$ & 8,19 & $0,28 \mathrm{a}$ & 4,88 & $0,20 \mathrm{a}$ & 2,65 & $0,15 \mathrm{~b}$ \\
\hline
\end{tabular}

Wartości w kolumnach oznaczone co najmniej jedną taką samą literą nie różnią się istotnie $(\alpha=0,05$ lub $\alpha=0,01)$

Values in columns marked with at least the same letter do not differ significantly ( $\alpha=0.05$ or $\alpha=0.01$ )

Tabela 5. Średnie wartości uszkodzenia roślin przez ploniarkę zbożówkę dla kombinacji $\mathrm{Y} \times \mathrm{B} \times \mathrm{C}$

Table 5. Mean values of damage of plants caused by frit fly for the combination $\mathrm{Y} \times \mathrm{B} \times \mathrm{C}$

\begin{tabular}{|c|c|c|c|c|c|c|c|c|c|}
\hline \multirow{3}{*}{ B } & \multirow{3}{*}{$\mathrm{C}$} & \multicolumn{8}{|c|}{ Lata - Years } \\
\hline & & \multicolumn{2}{|c|}{2015} & \multicolumn{2}{|c|}{2016} & \multicolumn{2}{|c|}{2017} & \multicolumn{2}{|c|}{2018} \\
\hline & & {$[\%]$} & ${ }^{\circ}$ Bliss & {$[\%]$} & ${ }^{\circ} \mathrm{B}$ liss & {$[\%]$} & ${ }^{\circ}$ Bliss & {$[\%]$} & ${ }^{\circ}$ Bliss \\
\hline \multirow{2}{*}{ B1 } & $\mathrm{C} 1$ & 2,38 & $0,15 \mathrm{~d}$ & 8,22 & $0,29 \mathrm{a}$ & 9,14 & $0,30 \mathrm{a}$ & 1,70 & $0,11 \mathrm{~d}$ \\
\hline & $\mathrm{C} 2$ & 5,63 & $0,24 \mathrm{abc}$ & 6,52 & $0,25 \mathrm{a}$ & 9,42 & $0,31 \mathrm{a}$ & 2,33 & $0,14 \mathrm{~d}$ \\
\hline \multirow{2}{*}{ B2 } & $\mathrm{C} 1$ & 2,84 & $0,16 \mathrm{~cd}$ & 6,39 & $0,24 \mathrm{ab}$ & 7,85 & $0,28 \mathrm{a}$ & 1,46 & $0,11 \mathrm{~d}$ \\
\hline & $\mathrm{C} 2$ & 3,12 & $0,17 \mathrm{bcd}$ & 8,09 & $0,28 \mathrm{a}$ & 6,81 & $0,26 \mathrm{a}$ & 1,51 & $0,10 \mathrm{~d}$ \\
\hline
\end{tabular}

Wartości w kolumnach oznaczone co najmniej jedną taką samą literą nie różnią się istotnie $(\alpha=0,01)$

Values in columns marked with at least the same letter do not differ significantly $(\alpha=0.01)$

podatności uszkodzonych roślin na porażenie przez choroby, których sprawcy mogą wytwarzać mikotoksyny, zwłaszcza grzyby odpowiedzialne za rozwój fuzariozy kolb oraz zgnilizny korzeni i zgorzeli podstawy łodygi (Dorn i wsp. 2009; Scauflaire i wsp. 2011; Mesterházy i wsp. 2012). Oscinella frit silniej uszkodziła rośliny w latach 2016-2017, przy czym termin aplikacji dawki azotu nie miał istotnego wpływu na wartość tej cechy. Istotnie najmniejsze uszkodzenia roślin przez $O$. frit odnotowano w roku 2018, niezależnie od terminu zastosowania dawki azotu. Natomiast istotnie najmniejsze uszkodzenia roślin kukurydzy przez O. melanopus wystąpiły w roku 2015, gdy zastosowano azot przed siewem kukurydzy. Zaobserwowano również (tab. 4), niezależnie od lat badań i głębokości aplikacji nawozu NP, istotnie najmniejsze uszkodzenia roślin przez tego szkodnika po zastosowaniu saletry amonowej lub mocznika przed siewem kukurydzy, a istotnie największe, gdy zastosowano saletrę amonową w fazie BBCH 15/16. Procent roślin uszkodzonych przez $O$. frit w istotny sposób kształtowany był zmiennymi warunkami pogodowymi w latach badań, rodzajem nawozu azotowego oraz terminem zastosowania uzupełniającej dawki azotu (tab. 5). Stwierdzono, że istotnie największe uszkodzenia roślin przez tego szkodnika wystąpiły w roku 2015, gdy zastosowano saletrę amonową w fazie 
5-6 liści rośliny (BBCH 15/16) oraz w latach 2016-2017, przy czym rodzaj nawozu azotowego oraz termin zastosowania uzupełniającej dawki azotu nie miały istotnego znaczenia. Istotnie najmniejsze uszkodzenia roślin przez $O$. frit zaobserwowano w 2015 roku, gdy zastosowano kombinację nawozową - saletra amonowa z przedsiewną aplikacją azotu oraz w 2018 roku, gdzie kombinacja obu tych czynników agrotechnicznych nie różnicowała wielkości uszkodzeń roślin kukurydzy przez tego szkodnika.

\section{Wnioski / Conclusions}

1. Procent roślin uszkodzonych przez szkodniki wykazywał zmienną reakcję na warunki pogodowe oraz czynniki doświadczalne.
2. Nie wykazano istotnego wpływu głębokości aplikacji nawozu NP na odsetek roślin kukurydzy uszkodzonych przez $O$. nubilalis, $O$. frit i $O$. melanopus.

3. Zastosowanie saletry amonowej w stosunku do mocznika zwiększało liczbę roślin kukurydzy uszkodzonych przez O. frit.

4. Aplikacja azotu w fazie BBCH 15/16 zwiększała presję $O$. melanopus na kukurydzy, w porównaniu do przedsiewnej aplikacji tego składnika.

5. Niezależnie od lat badań i głębokości aplikacji nawozu $\mathrm{NP}$, istotnie najmniejsze uszkodzenia roślin przez O. melanopus odnotowano po zastosowaniu saletry amonowej lub mocznika przed siewem kukurydzy, a istotnie największe, gdy zastosowano saletrę amonową w fazie BBCH 15/16.

\section{Literatura / References}

Belanger G., Claessens A., Ziadi N. 2011. Relationship between P and N concentration in maize and wheat leaves. Field Crops Research 123 (1): 28-37. DOI: $10.1016 /$ j.fcr.2011.04.007

Bereś P.K. 2011. Usefulness of selected seed dressing insecticides for integrated maize (Zea mays L.) protection against frit fly (Oscinella frit L.). [Przydatność wybranych insektycydowych zapraw nasiennych $\mathrm{w}$ integrowanej ochronie kukurydzy (Zea mays L.) przed ploniarką zbożówką (Oscinella frit L.)]. Acta Scientiarum Polonorum, Agricultura 10 (4): 15-23.

Bocianowski J., Szulc P., Tratwal A., Nowosad K., Piesik D. 2016. The influence of potassium to mineral fertilizers on the maize health. Journal of Integrative Agriculture 15 (6): 1286-1292. DOI: 10.1016/S2095-3119(15)61194-7

Ciampitti I.A., Vyn T.J. 2013. Maize nutrient accumulation and partitioning in response to plant density and nitrogen rate: II. Calcium, magnesium, and micronutrients. Agronomy Journal 105 (6): 1645-1657. DOI: 10.2134/agronj2013.0126

Dorn B., Forrer H.R., Schürch S., Vogelgsang S. 2009. Fusarium species complex on maize in Switzerland: occurrence, prevalence, impact and mycotoxins in commercial hybrids under natural infection. European Journal of Plant Pathology 125: 51-61. DOI: 10.1007/ s10658-009-9457-8

Dyrektywa 2009. Dyrektywa Parlamentu Europejskiego i Rady 2009/128/WE z dnia 21.10.2009 roku ustanawiająca ramy wspólnotowego działania na rzecz zrównoważonego stosowania pestycydów (Dz.U. UE L 309/71 z 24.11.2009 r.).

Grzebisz W., Barłóg P., Waszak M., Łukowiak R. 2007. Homeostaza żywieniowa a odporność roślin uprawnych na stresy biotyczne. [Nutritional homeostasis and plant crops resistance to biotic stresses]. Fragmenta Agronomica 24 (3): 136-143.

Krauss A. 2001. Potassium and biotic stress. 1st FAUBA - Fertilizer - IPI Workshop on Potassium in Argentina Agricultural System. Buenos Aires, Argentyna, November 20-21, 2001, 11 ss.

Ladha K.J., Pathak H., Krupnik J.T., Six J., Van Kessel Ch. 2005. Efficiency of fertilizer nitrogen in cereal production: retrospects and prospects. Advances in Agronomy 87: 85-156. DOI: 10.1016/s0065-2113(05)87003-8

Mesterházy Á., Lemmens M., Reid L.M. 2012. Breeding for resistance to ear rots caused by Fusarium ssp. in maize - a review. Plant Breeding 131 (1): 1-19. DOI: 10.1111/j.1439-0523.2011.01936.x

Molga M. 1986. Meteorologia rolnicza. Powszechne Wydawnictwo Rolnicze i Leśne, Warszawa: 470-475.

Scauflaire J., Mahieu O., Louveaux J., Foucart G., Renard F., Munaut F. 2011. Biodiversity of Fusarium species in ears and stalks of maize plants in Belgium. European Journal of Plant Pathology 131: 59-66. DOI: 10.1007/s10658-011-9787-1

Scharf P.C., William J., Wiebold J., Lory J.A. 2002. Corn yield response to nitrogen fertilizer timing and deficiency level. Agronomy Journal 94 (3): 435-441. DOI: 10.2134/agronj2002.4350

Setiyono T.D., Walters D.T., Cassman K.G., Witt C., Dobermann A. 2010. Estimating maize nutrient uptake requirements. Field Crops Research 118 (2): 158-168. DOI: 10.1016/j.fcr.2010.05.006

Szulc P. 2013. Nawożenie organiczne i mineralne kukurydzy kształtujące występowanie chorób fuzaryjnych (Fusarium spp.) oraz omacnicy prosowianki (Ostrinia nubilalis Hbn.). [Organic and mineral fertilization of maize affecting prevalence of fusarium diseases (Fusarium spp.) and European corn borer (Ostrinia nubilalis Hbn.)]. Progress in Plant Protection/Postępy w Ochronie Roślin 53 (3): 498-502. DOI: 10.14199/ppp-2013-053

Szulc P., Bocianowski J. 2014. Susceptibility of maize hybrids (Zea mays L.) to frit fly (Oscinella frit L.) under conditions of diversified nitrogen content in the soil and different types of nitrogen fertilizers. [Podatność mieszańców kukurydzy (Zea mays L.) na ploniarkę zbożówkę (Oscinella frit L.) w warunkach zróżnicowanej zasobności gleby w azot i rodzaj nawozu azotowego]. Acta Scientiarum Polonorum, Agricultura 13 (2): 63-77.

Szulc P., Rybus-Zając M., Jagła M. 2015. Influence of maize hybrid type (Zea mays L.) and N dose on nitrogen eutrophication of the environment. Electronic Journal of Polish Agricultural Universities 18 (2): \#08.

Szulc P., Waligóra H., Michalski T., Bocianowski J., Rybus-Zając M., Wilczewska W. 2018. The size of the $\mathrm{N}_{\min }$ soil pool as a factor impacting nitrogen utilization efficiency in maize (Zea mays L.). Pakistan Journal of Botany 50 (1): 189-198.

Ziadi N., Bélanger G., Cambourus A.N., Tremblay N., Nolin M.C., Claessens A. 2007. Relationship between P and N concentrations in corn. Agronomy Journal 99 (3): 833-841. DOI: 10.2134/agronj2006.0199 